\title{
Possible role of TLR4 and TLR9 SNPs in protection against congenital toxoplasmosis
}

\author{
W. Wujcicka ${ }^{1,2} \cdot$ Z. Gaj $^{1,2}$ - J. Wilczyński ${ }^{2}$ - D. Nowakowska ${ }^{2}$
}

Received: 9 March 2015 / Accepted: 20 July 2015 / Published online: 9 August 2015

(C) The Author(s) 2015. This article is published with open access at Springerlink.com

\begin{abstract}
The purpose of this investigation was the determination of the distribution of genotypes at single nucleotide polymorphisms (SNPs) of the toll-like receptor 4 (TLR4) and the toll-like receptor 9 (TLR9) in fetuses and newborns congenitally infected with Toxoplasma gondii and the identification of genetic changes predisposing to infection development. The study involved 20 fetuses and newborns with congenital toxoplasmosis and 50 uninfected controls. The levels of IgG and IgM antibodies against $T$. gondii, as well as IgG avidity, were estimated by enzyme-linked fluorescent assay (ELFA) tests. T. gondii DNA loads in amniotic fluids were assayed by the real-time (RT) quantitative polymerase chain reaction (Q PCR) technique for parasitic B1 gene. TLR4 and TLR9 SNPs were identified using a self-designed multiplex nested PCR-restriction fragment length polymorphism (RFLP) assay. Randomly selected genotypes at SNPs were confirmed by sequencing. All the genotypes were tested for Hardy-Weinberg equilibrium and TLR4 genotypes were analyzed for linkage disequilibrium. A correlation was studied between the genotypes or haplotypes and the development of congenital toxoplasmosis using a logistic regression model. Single SNP analysis showed no statistically significant differences in the distribution of distinct genotypes at the analyzed TLR4 and TLR9 SNPs between T. gondii-infected fetuses and newborns and the controls. Taking into account the prevalence
\end{abstract}

W. Wujcicka

wwujcicka@yahoo.com

1 Scientific Laboratory of the Center of Medical Laboratory Diagnostics, Polish Mother's Memorial Hospital-Research Institute, 281/289 Rzgowska Street, Lodz 93-338, Poland

2 Department of Perinatology and Gynecology, Polish Mother's Memorial Hospital—Research Institute, Lodz, Poland of alleles residing within polymorphic sites, similar prevalence rates were observed in both of the studied groups. The multiple SNP analysis indicated GTG variants at the TLR4 and TLR 9 SNPs to be significantly less frequent in offspring with congenital toxoplasmosis than in uninfected offspring $(p \leq 0.0001) . T L R 4$ and TLR9 SNPs seem to be involved in protection against congenital toxoplasmosis.

\section{Introduction}

Intrauterine infections are among the major causes of perinatal morbidity and mortality. Nearly $40 \%$ of pregnant Polish women are infected with Toxoplasma gondii [1-3]. Particularly dangerous are primary infections in pregnant women, which are usually asymptomatic and, in approximately 30 $50 \%$ of patients, result in transplacental transmission of T. gondii to the fetus [4]. In fetuses and newborns with immature immune systems, consequential congenital infections may bring about a very severe, if not fatal, course $[4,5]$. Congenital toxoplasmosis occurs in approximately 0.07 $2.9 \%$ of live births.

Toll-like receptor (TLR)/MyD88 signaling has been reported as the key pathway in a non-specific antimicrobial response against $T$. gondii $[6,7]$. The glycosylphosphatidylinositol (GPI) of T. gondii was demonstrated to trigger TLR4 signaling pathways [8-10]. In inflammatory monocytes, T. gondii infection induced the production of interferon (IFN)- $\beta$ through TLR4 and MyD88 signaling [11]. A lack of tumor necrosis factor (TNF) expression after $T$. gondii infection was characteristic for mice deficient in TLR2 and TLR4, but not in TLR2 molecules alone [8]. Also, TLR9 might have an important role in the immunity against $T$. gondii, since TLR9-deficient mice, infected with the parasite, were comparatively resistant to the ileitis, revealing a decreased Th1 immune response $[12,13]$. 
Taking into account $T L R$ genetic changes, possibly involved in the development of $T$. gondii infections, the TLR9 1635 $\mathrm{A}>\mathrm{G}$ single nucleotide polymorphism (SNP) was reported to be associated with toxoplasmic retinochoroiditis among Brazilian children with ocular toxoplasmosis [14]. So far, no paper has ever reported the role of TLR4 and TLR9 SNPs in the development of congenital infections with $T$. gondii. However, previous studies commonly showed the role of TLR4 896 $\mathrm{A}>\mathrm{G}$ and $1196 \mathrm{C}>\mathrm{T}$ SNPs in several pregnancy disorders, including premature rupture of membranes (PROM), bronchopulmonary dysplasia, and preterm labor $[6,15,16]$. In turn, the TLR9 $1635 \mathrm{~A}>\mathrm{G}$ SNP was also reported to be involved in cervical cancer, mother-to-child transmission (MTCT) of human immunodeficiency virus type 1 (HIV-1), and an increased risk of low birth weight in infants, a risk of maternal anemia, as well as a clinical picture of malaria in pregnancy [17-19].

Considering the role of TLR molecules in the development of $T$. gondii infection, as well as TLR genetic changes in pregnancy disorders, we decided to describe in this report the prevalence rates of the genotypes and alleles at the TLR4 $896 \mathrm{~A}>\mathrm{G}, 1196 \mathrm{C}>\mathrm{T}$, and TLR9 $1635 \mathrm{G}>\mathrm{A}$ SNPs in fetuses and newborns congenitally infected with $T$. gondii and compare them to the prevalence rates observed in uninfected controls. The haplotype prevalence rates were analyzed for TLR 4 SNPs as well. Moreover, a multiple SNP analysis was performed to identify the combined TLR SNP variants possibly involved in the immune response against $T$. gondii. Additionally, we also determined genotypes and alleles at the TLR2 $2258 \mathrm{G}>\mathrm{A}$ SNP (rs5743708) among the studied groups of patients. However, in the case of the TLR2 SNP, no contribution was found to congenital infection with $T$. gondii; hence, no molecular data on this polymorphism were shown in the current study.

\section{Materials and methods}

The study was performed with 20 fetuses and newborns with congenital toxoplasmosis and 50 control fetuses and newborns without $T$. gondii intrauterine infection. Samples were collected both retrospectively (15 infected cases and 23 controls) and prospectively (five infected cases and 27 controls). The specimens, selected for genetic studies of the infected patients, included fetal amniotic fluid samples, obtained via amniocentesis in pregnant women, all of them treated at the Polish Mother's Memorial Hospital Research Institute in Lodz, between the years 2000 and 2014. The diagnosis of intrauterine infections was based on maternal serological tests and the clinical picture, including flu-like symptoms, fetal and neonatal ultrasound markers related to the diseases, and the presence of parasite or viral DNA in body fluids of the patients. Congenital infections with $T$. gondii were confirmed by the presence of pathogen DNA in body fluids (amniotic and/or ascitic fluids, umbilical cord blood) of the fetuses and newborns. The group of control cases included the offspring of pregnant women seronegative for $T$. gondii. The study was approved by the Research Ethics Committee at the Polish Mother's Memorial Hospital Research Institute. The samples, previously collected for diagnostic purposes and anonymized, were used for molecular analysis. Informed consent forms were signed by the enrolled pregnant women prior to the study.

\section{Serological tests}

Blood specimens were collected from the pregnant women participating in the study by venipuncture on the first visit to the Institute. Serum samples were obtained by centrifugation and then stored at $4{ }^{\circ} \mathrm{C}$ before analysis. Serological tests were performed at the Department of Clinical Microbiology of the Institute.

Screening for T. gondii $\operatorname{IgG}$ antibodies was performed with the enzyme-linked fluorescent assay (ELFA) VIDAS TOXO IgG II (bioMérieux), while the levels of IgM antibodies were estimated with the ELFA assay VIDAS TOXO IgM (bioMérieux). T. gondii IgG avidity was determined using the ELFA assay VIDAS TOXO IgG Avidity (bioMérieux). The pregnant women were determined as possibly infected with $T$. gondii in case of seroconversion during pregnancy and/or serology, suggesting recent infection, based on IgM seropositivity, as well as on low IgG avidity index. In order to confirm recent infection, the suspected women, as well as their fetuses and newborns, were tested for the presence of parasite DNA, using real-time (RT) quantitative polymerase chain reaction (Q PCR) assays for $T$. gondii $B 1$ gene fragments.

\section{DNA isolation}

Genomic DNA was extracted from $5 \mathrm{ml}$ of the amniotic fluid, from $3 \mathrm{ml}$ of the cerebrospinal fluid, or from $200 \mu \mathrm{l}$ of the umbilical cord blood of the fetuses, using a High Pure PCR Template Preparation Kit (Roche, Mannheim, Germany), and submitted to genetic studies of congenital toxoplasmosis. The extracted DNA was diluted in $100 \mu \mathrm{l}$ of elution buffer and stored at $-20^{\circ} \mathrm{C}$ until molecular analyses.

\section{Detection and quantification of $T$. gondii DNA}

Parasite DNA was identified and quantified by a RT Q PCR assay for a $B 1$ gene fragment of $83 \mathrm{bps}$ in length, as previously described [20]. Forward and reverse primers and TaqMan MGB probe sequences were as follows: 5' CAA GCA GCG TAT T G T C GA GTA GAT-3', 5' GCGTCTCTTTCATTCCCACATTTT-3', and 5'-6-FAM- 
CAGAAAGGAACTGCATCCGTT-NFQ-3', respectively [20]. Standard curves, used in the quantitative analyses, were plotted with serial 10 -fold dilutions from $10^{5}$ to 1 copy of T. gondii RH strain (tebu-bio; 08-948-250). T. gondii DNA copy numbers, present in PCR samples, were determined by the absolute quantification analysis, done automatically by the software, applied with the RT PCR instrument. RT Q PCR assays were performed using a LightCycler ${ }^{\circledR} 2.0$ Instrument (Roche, Mannheim, Germany).

\section{Determination of SNPs located in TLR4 and TLR9 genes}

The TLR4 $896 \mathrm{~A}>\mathrm{G}$ and $1196 \mathrm{C}>\mathrm{T}$ SNPs and the TLR9 1635 $\mathrm{G}>\mathrm{A}$ SNP were determined using the self-designed multiplex nested PCR assay described in our recent paper [21]. The sequences of external and internal primers, amplicon lengths, and annealing temperatures used in the multiplex PCR are shown in Table 1. External primer sequences were designed using the Vector NTI Suite 5.5 software, whereas the internal primers were taken from the literature [22-24]. Multiplex nested PCR products were digested with NcoI, HinfI, or BstuI endonucleases to determine the genotypes at the TLR4 896 A $>$ G, TLR4 $1196 \mathrm{C}>\mathrm{T}$, or TLR9 $1635 \mathrm{G}>\mathrm{A}$ SNPs, respectively. TLR SNPs and genotypes were discriminated based on the length of restriction fragments ([22-24]; see Table 1, Fig. 1). Genotypes at the TLR4 896 A > G SNP were assessed for 69 out of the 70 studied fetuses and neonates, at the TLR4 1196 C $>$ T SNP for 59 out of the 70 patients, while the genetic variants at the TLR9 $1635 \mathrm{G}>\mathrm{A}$ SNP were assessed for 64 out of the 70 analyzed offspring. Randomly selected PCR products for the TLR4 and TLR9 SNP genotypes were then sequenced by the Sanger method to confirm the outcomes of the multiplex nested PCR-restriction fragment length polymorphism (RFLP) assay. In case of TLR4 SNPs, the sequencing was performed for three AA homozygotes and one AG heterozygote at the TLR4 $896 \mathrm{~A}>\mathrm{G}$ SNP, as well as for two CC homozygotes and one CT heterozygote at the TLR4 $1196 \mathrm{C}>\mathrm{T}$ SNP. Considering the TLR9 SNP, the sequencing was performed for four GG homozygotes, ten GA heterozygotes, and three AA homozygotes. The chromatograms, which illustrate the DNA sequences of PCR products for different TLR SNPs, are shown in Fig. 2. Both the sequenced and the reference fragments of the analyzed TLR genes were compared, using the BLASTN program for alignment of two (or more) sequences (http://blast.ncbi.nlm.nih.gov/Blast.cgi?PAGE TYPE $=$ BlastSearch\&BLAST_SPEC $=$ blast2seq\&LINK LOC $=$ align2seq), and chromatograms were read using the Sequence Scanner 1.0 and the Chromas Lite 2.1.1 programs.

\section{Statistical analysis}

The prevalence rates of genotypes and alleles at the TLR 4 and TLR9 SNPs that were identified in the examined fetuses and newborns, both those infected with $T$. gondii and the controls, were estimated by means of descriptive statistics. The study groups were tested for the Hardy-Weinberg (H-W) equilibrium, linkage disequilibrium (LD), and haplotypes using the SNPStats software (http://bioinfo.iconcologia.net/en/ SNPStats_web). The relationship between the genotypes or alleles at the TLR SNPs and the development of $T$. gondii infection was determined using cross-tabulation and Pearson's Chi-squared test, as well as the logistic regression model. The estimation of haplotypes at the TLR4 SNPs, as well as the multiple SNP analysis, was performed employing the

Table 1 Primers, annealing temperatures, and the lengths of products obtained in the multiplex nested polymerase chain reaction (PCR) assay for single nucleotide polymorphisms (SNPs) in the toll-like receptor 4 (TLR4) and toll-like receptor 9 (TLR9) genes

\begin{tabular}{|c|c|c|c|c|c|c|c|}
\hline Gene & $\mathrm{SNP}^{\mathrm{a}}$ name & Primer se & quences $\left(5^{\prime}-3^{\prime}\right)$ & $\begin{array}{l}\text { Annealing } \\
\text { temperature }\left({ }^{\circ} \mathrm{C}\right)\end{array}$ & $\begin{array}{l}\text { Amplicon } \\
\text { length (bps) }\end{array}$ & $\begin{array}{l}\text { Restriction } \\
\text { enzyme }\end{array}$ & Profile (bps) \\
\hline \multirow[t]{4}{*}{ TLR4 } & \multirow{2}{*}{$\begin{array}{l}896 \mathrm{~A}>\mathrm{G} \\
\quad(1063 \mathrm{~A}>\mathrm{G} \\
\quad \mathrm{rs} 4986790)\end{array}$} & External & $\begin{array}{l}\text { For: AAAACTTGTATTCAAGGTCTGGC } \\
\text { Rev: TGTTGGAAGTGAAAGTAAGCCT }\end{array}$ & 52 & 355 & \multirow[t]{2}{*}{ NcoI } & \multirow{2}{*}{$\begin{array}{l}\text { AA: } 188 \\
\text { AG: } 188,168,20 \\
\text { GG: } 168,20\end{array}$} \\
\hline & & Internal & $\begin{array}{l}\text { For: AGCATACTTAGACTACTACCTCCATG } \\
\text { Rev: AGAAGATTTGAGTTTCAATGTGGG }\end{array}$ & 61 & 188 & & \\
\hline & \multirow{2}{*}{$\begin{array}{l}1196 \mathrm{C}>\mathrm{T} \\
\quad(1363 \mathrm{C}>\mathrm{T} \\
\mathrm{rs} 4986791)\end{array}$} & External & $\begin{array}{l}\text { For: AGTTGATCTACCAAGCCTTGAGT } \\
\text { Rev: GGAAACGTATCCAATGAAAAGA }\end{array}$ & 52 & 510 & \multirow[t]{2}{*}{ Hinfl } & \multirow{2}{*}{$\begin{array}{l}\text { CC: } 407 \\
\text { CT: } 407,378,29 \\
\text { TT: } 378,29\end{array}$} \\
\hline & & Internal & $\begin{array}{l}\text { For: GGTTGCTGTTCTCAAAGTGATTTT } \\
\text { GGGAGAA } \\
\text { Rev: ACCTGAAGACTGGAGAGT } \\
\text { GAGTTAAATGCT }\end{array}$ & 59 & 407 & & \\
\hline \multirow[t]{2}{*}{ TLRO } & \multirow{2}{*}{$\begin{array}{l}1635 \mathrm{G}>\mathrm{A} \\
\quad(2848 \mathrm{G}>\mathrm{A} \\
\quad \mathrm{rs} 352140)\end{array}$} & External & $\begin{array}{l}\text { For: GTCAATGGCTCCCAGTTCC } \\
\text { Rev: CATTGCCGCTGAAGTCCA }\end{array}$ & 52 & 292 & \multirow[t]{2}{*}{ BstUI } & \multirow{2}{*}{$\begin{array}{l}\text { GG: } 135,42 \\
\text { GA: } 177,135,42 \\
\text { AA: } 177\end{array}$} \\
\hline & & Internal & $\begin{array}{l}\text { For: AAGCTGGACCTCTACCACGA } \\
\text { Rev: TTGGCTGTGGATGTTGTT }\end{array}$ & 59 & 177 & & \\
\hline
\end{tabular}

\footnotetext{
${ }^{\text {a }} S N P$ single nucleotide polymorphism
}

${ }^{\mathrm{b}}$ bps base pairs 

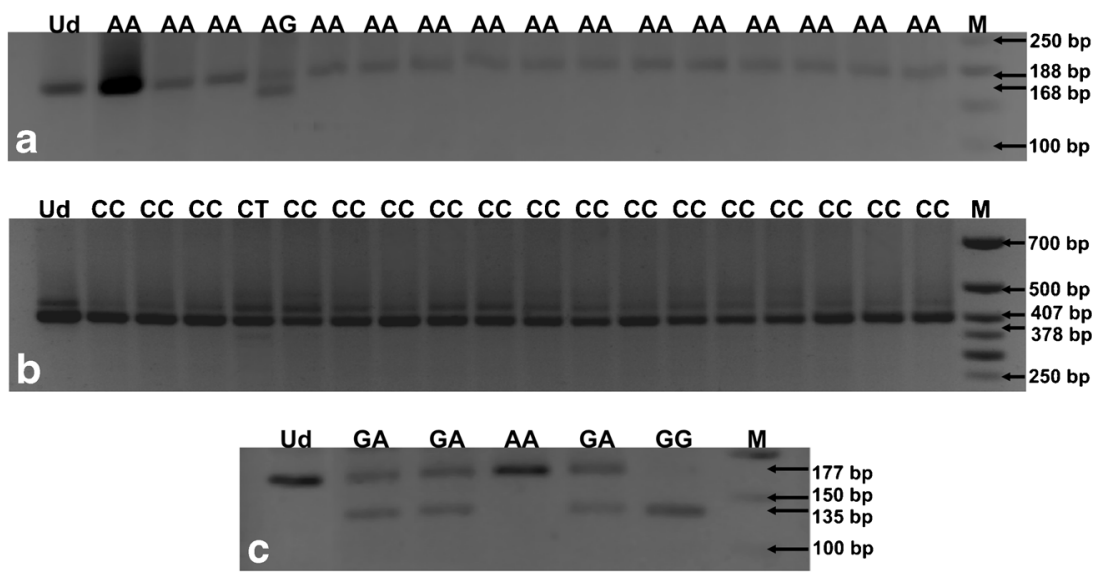

Fig. 1 Agarose gel electrophoresis of polymerase chain reactionrestriction fragment length polymorphism (PCR-RFLP) products for profiling genotypes at the toll-like receptor 4 (TLR4) $896 \mathrm{~A}>\mathrm{G}$ singlenucleotide polymorphism (SNP) (a), the TLR4 $1196 \mathrm{C}>\mathrm{T}$ SNP (b), and the TLR9 $1635 \mathrm{G}>\mathrm{A}$ SNP (c). DNA fragments which resulted from the restriction analyses performed with $\mathrm{NcoI}$ (a), HinfI (b), and BstUI (c)

expectation-maximization (EM) algorithm. All the results were determined to be statistically significant when they reached the significance level of $p \leq 0.050$. The statistical analysis was, in part, supported by the NCSS 97 software.

\section{Results}

\section{T. gondii DNA loads in fetal and neonatal body fluids}

The median load of T. gondii DNA in the collected fetal amniotic fluid samples was $6.5 \times 10^{2}$ copies $/ \mathrm{ml}$ and ranged from 3.0 to $9.7 \times 10^{3}$ copies $/ \mathrm{ml}$, while the mean parasitic load was $2.0 \times 10^{3}$ copies $/ \mathrm{ml}$. In case of cerebrospinal fluid samples, the median $T$. gondii DNA load was $1.5 \times 10^{2}$ copies $/ \mathrm{ml}$, ranging from $1.1 \times 10$ to $1.2 \times 10^{5}$ copies $/ \mathrm{ml}$, and the mean parasitic load was $3.0 \times 10^{4}$ copies $/ \mathrm{ml}$. In neonatal umbilical cord blood specimens, the parasitic load was $7.5 \times 10^{3}$ copies $/ \mathrm{ml}$.

\section{Hardy-Weinberg equilibrium, linkage disequilibrium}

The genotypes at the TLR4 $896 \mathrm{~A}>\mathrm{G}$ SNP preserved the H-W equilibrium in $T$. gondii-infected fetuses and newborns $(p=$ $1.000)$, while they were not in the H-W equilibrium among the uninfected cases $(p \leq 0.050)$. The genotypes at the TLR4 $1196 \mathrm{C}>\mathrm{T}$ SNP did not preserve the $\mathrm{H}-\mathrm{W}$ equilibrium in either of the analyzed groups $(p \leq 0.050)$. In turn, the prevalence rates of genotypes at the analyzed TLR $91635 \mathrm{G}>\mathrm{A}$ SNP were in the $\mathrm{H}-\mathrm{W}$ equilibrium, both in the infected subjects as well as in uninfected controls $(p=1.000)$. The TLR4 $896 \mathrm{~A}>\mathrm{G}$ and 1196 $\mathrm{C}>\mathrm{T}$ SNPs were seen in linkage disequilibrium among both the infected and the control offspring $(p \leq 0.050)$. endonucleases were separated in $2 \%$ agarose gels and stained with ethidium bromide. The numbers on the right-hand side show the size of resolved DNA fragments. $M$ 50-bp DNA marker; $U d$ undigested PCR product; $A A, A G, G G, G A, C C, C T, T T$ genotypes at the studied $T L R$ polymorphisms

Prevalence rates of the genotypes at the $T L R 4896 \mathrm{~A}>\mathrm{G}$, 1196 C $>$ T, and TLR9 1635 G $>$ A SNPs

Among the fetuses and newborns infected with T. gondii, the prevalence rates of the AA and AG genotypes at the TLR4 896 A $>$ G SNP were $94.7 \%$ (18/19) and $5.3 \%$ (1/19), respectively (see Table 2). In case of the TLR4 $1196 \mathrm{C}>\mathrm{T}$ SNP, the CC and CT genotypes were observed in $94.4 \%(17 / 18)$ and $5.6 \%$ (1/18) of the patients, respectively. For the TLR9 $1635 \mathrm{G}>\mathrm{A}$ SNP, the GG, GA, and AA genotypes occurred in $20.0 \%$ (4/20), 55.0\% (11/20), and $25.0 \%(5 / 20)$ of the fetuses and newborns, respectively. Among the uninfected patients, the prevalence rates of the $\mathrm{AA}, \mathrm{AG}$, and GG genotypes at the TLR4 $896 \mathrm{~A}>\mathrm{G}$ SNP were $94.0 \%$ (47/50), $2.0 \%(1 / 50)$, and $4.0 \%(2 / 50)$, respectively. The CC, CT, and TT genotypes at the TLR4 $1196 \mathrm{C}>\mathrm{T}$ SNP were carried by $87.8 \%(36 / 41)$, $7.3 \%(3 / 41)$, and $4.9 \%$ (2/41) of cases, respectively. Regarding the TLR9 SNP, the prevalence rates of the GG, GA, and AA genotypes were $18.2 \%$ (8/44), $47.7 \%(21 / 44)$, and $34.1 \%$ (15/44), respectively. No relationship was observed between single genotypes at the studied TLR SNPs and congenital toxoplasmosis development. Taking into account all the analyzed SNPs, the multiple ACG variant at the TLR4 $896 \mathrm{~A}>\mathrm{G}, 1196 \mathrm{C}>\mathrm{T}$, and TLR9 $1635 \mathrm{G}>\mathrm{A}$ polymorphic sites was most common among the fetuses and newborns with congenital toxoplasmosis, with a prevalence rate of $52.8 \%$. In the group of congenitally infected offspring, the ACA and GTA variants were less frequently observed $(44.5 \%$ and $2.8 \%$, respectively). Considering the uninfected controls, the most common multiple variant was ACA (56.6\%), while the ACG, GTA, ATG, and GTG variants were less frequently observed $(34.9 \%, 4.4 \%, 2.4 \%$, and $1.7 \%$, respectively). The GTG variants were significantly less frequent among the fetuses and newborns with congenital toxoplasmosis as 


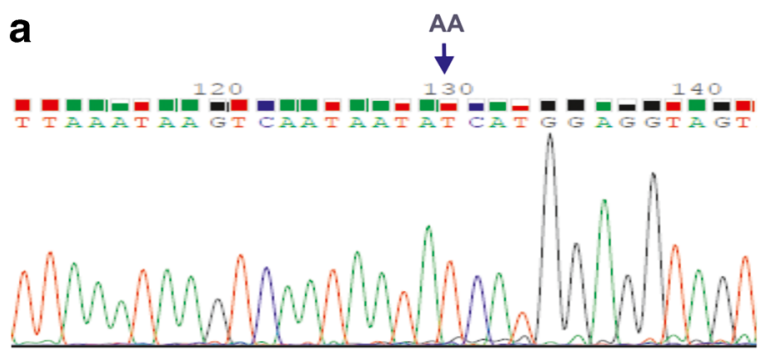

C
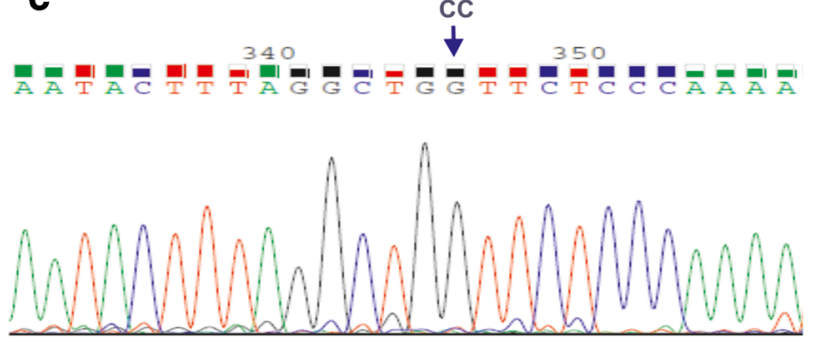

\section{e}

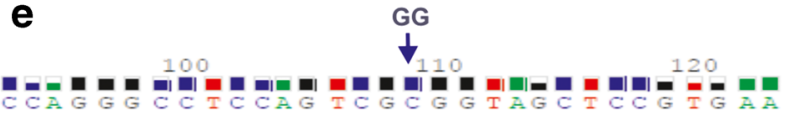

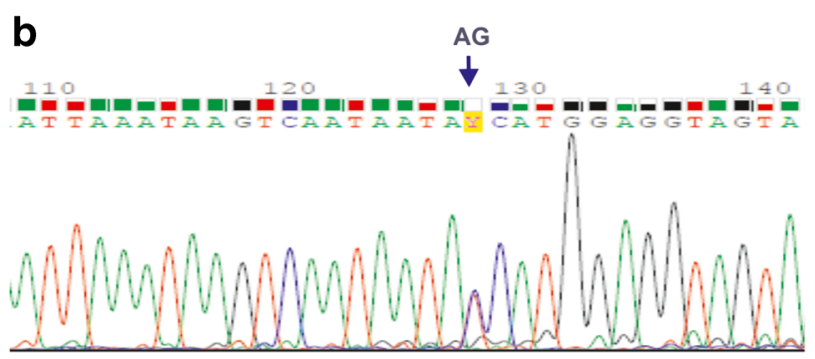

d

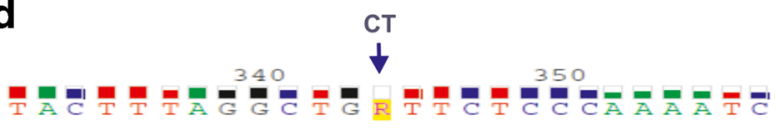

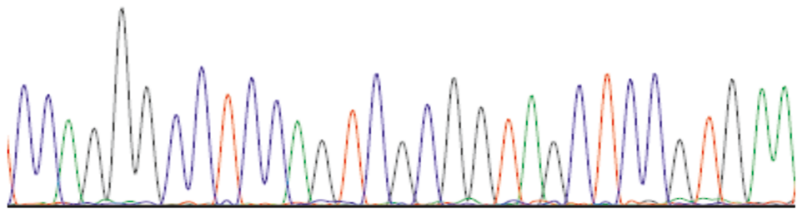
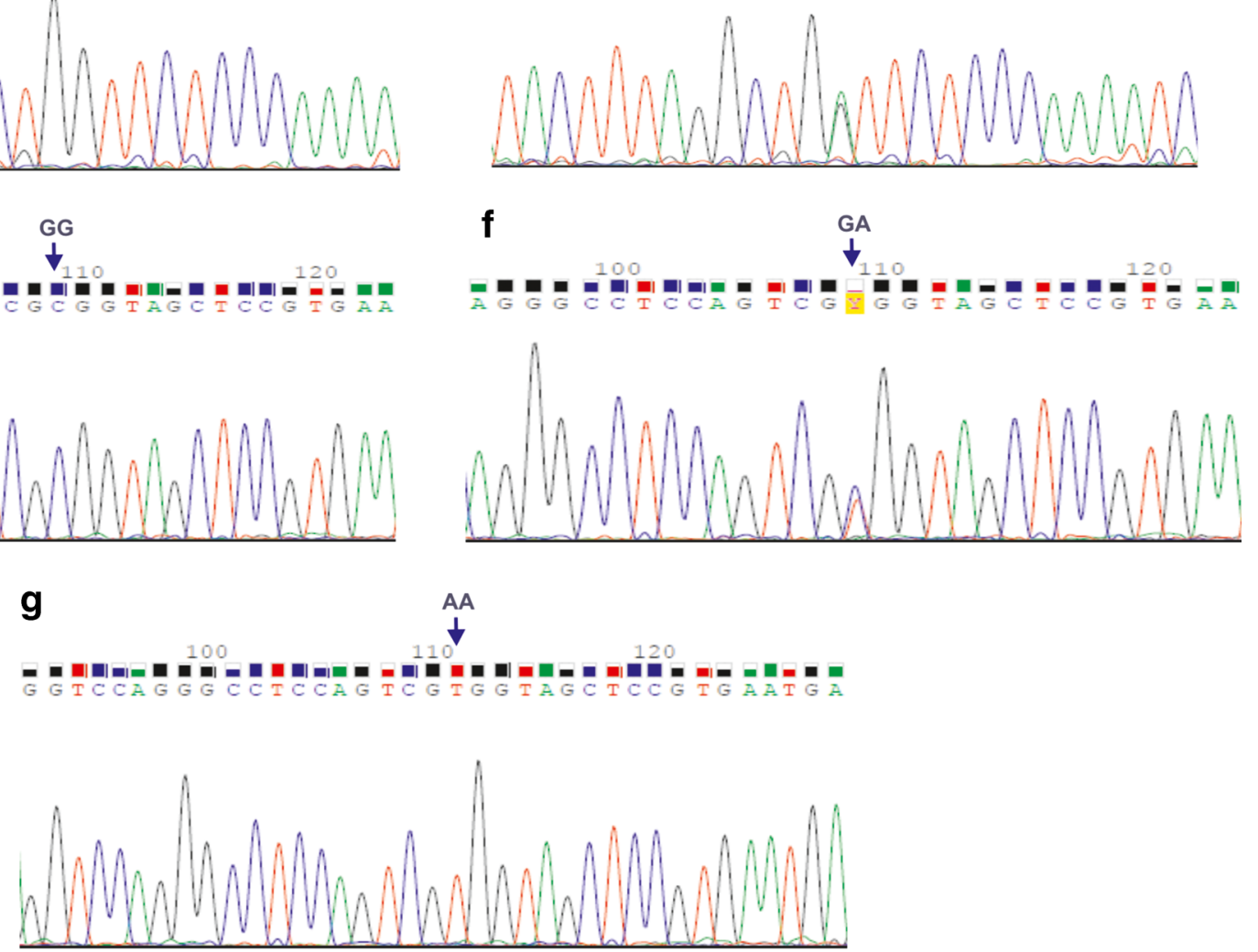

Fig. 2 Chromatograms of DNA sequences containing the TLR4 $896 \mathrm{~A}>\mathrm{G}$ SNP $(\mathbf{a}, \mathbf{b})$, the TLR4 $1196 \mathrm{C}>\mathrm{T}$ SNP $(\mathbf{c}$, d), and the TLR9 $1635 \mathrm{G}>\mathrm{A}$ SNP (eg). DNA reverse strands were sequenced for all the analyzed SNPs. $A A, A G, C C, C T, G G, G A$ genotypes at the described TLR SNPs

compared to the uninfected offspring $[0.0 \%$ vs. $1.7 \%$, respectively; odds ratio (OR) $\left.6.0 \times 10^{7} ; p \leq 0.0001\right]$.

\section{The prevalence rates of the alleles located at the $T L R 4$ and TLR9 SNPs}

In the $T$. gondii-infected fetuses and newborns, the prevalence rates of A and $\mathrm{G}$ alleles at the TLR4 $896 \mathrm{~A}>\mathrm{G}$ SNP were $97.4 \%(37 / 38)$ and $2.6 \%(1 / 38)$, respectively (see Table 3 ). Considering the TLR4 $1196 \mathrm{C}>\mathrm{T}$ SNP, the prevalence rates of $\mathrm{C}$ and $\mathrm{T}$ alleles were $97.2 \%(35 / 36)$ and $2.8 \%(1 / 36)$, respectively. At the region of the TLR9 SNP, the G allele was observed with a prevalence rate of $47.5 \%(19 / 40)$, while the A allele was observed with a prevalence rate of $52.5 \%(21 / 40)$. Among the uninfected control fetuses and newborns, within the TLR4 $896 \mathrm{~A}>\mathrm{G}$ polymorphic region, the $\mathrm{A}$ allele was observed with a prevalence rate of $95.0 \%(95 / 100)$, while the $\mathrm{G}$ allele was observed with a prevalence rate of $5.0 \%$ (5/100). At the TLR4 $1196 \mathrm{C}>\mathrm{T}$ SNP, the C allele occurred with a prevalence rate of $91.5 \%(75 / 82)$, while the $\mathrm{T}$ allele occurred with a prevalence rate of $8.5 \%(7 / 82)$. In case of the TLR9 SNP, the G allele was observed with a prevalence rate of $58.0 \%(51 / 88)$, while the $\mathrm{G}$ allele was observed with a prevalence rate of $42.0 \%$ (37/88). In case of the TLR4 $1196 \mathrm{C}>\mathrm{T}$ SNP, the prevalence rate of the major allele was slightly increased among the infected patients compared to the 
Table 2 Single SNP analysis of the relationship between TLR polymorphisms and congenital Toxoplasma gondii infection

\begin{tabular}{|c|c|c|c|c|c|c|}
\hline \multirow[t]{2}{*}{ Gene polymorphism } & \multirow[t]{2}{*}{ Genetic model } & \multirow[t]{2}{*}{ Genotype } & \multicolumn{2}{|c|}{ Genotype prevalence rates; $n(\%)^{\mathrm{a}}$} & \multirow[t]{2}{*}{$\mathrm{OR}^{\mathrm{b}}(95 \% \mathrm{CI})^{\mathrm{c}}$} & \multirow[t]{2}{*}{$p$-Value } \\
\hline & & & Infected cases & Uninfected controls & & \\
\hline \multirow[t]{10}{*}{$T L R 4896 \mathrm{~A}>\mathrm{G}$} & \multirow[t]{3}{*}{ Codominant } & AA & $18(94.7 \%)$ & $47(94 \%)$ & 1.00 & \multirow[t]{3}{*}{0.420} \\
\hline & & $\mathrm{AG}$ & $1(5.3 \%)$ & $1(2 \%)$ & $2.61(0.15-44.01)$ & \\
\hline & & GG & $0(0 \%)$ & $2(4 \%)$ & $0.00(0.00-\mathrm{NA})$ & \\
\hline & Dominant & AA & $18(94.7 \%)$ & $47(94 \%)$ & 1.00 & \multirow[t]{2}{*}{0.910} \\
\hline & & AG-GG & $1(5.3 \%)$ & $3(6 \%)$ & $0.87(0.08-8.92)$ & \\
\hline & Recessive & AA-AG & $19(100 \%)$ & $48(96 \%)$ & 1.00 & \multirow[t]{2}{*}{0.250} \\
\hline & & GG & $0(0 \%)$ & $2(4 \%)$ & $0.00(0.00-\mathrm{NA})$ & \\
\hline & Overdominant & AA-GG & $18(94.7 \%)$ & $49(98 \%)$ & 1.00 & \multirow[t]{2}{*}{0.490} \\
\hline & & $\mathrm{AG}$ & $1(5.3 \%)$ & $1(2 \%)$ & $2.72(0.16-45.85)$ & \\
\hline & Log-additive & - & - & - & $0.66(0.12-3.75)$ & 0.620 \\
\hline \multirow[t]{10}{*}{ TLR4 $1196 \mathrm{C}>\mathrm{T}$} & Codominant & $\mathrm{CC}$ & $17(94.4 \%)$ & $36(87.8 \%)$ & 1.00 & \multirow[t]{3}{*}{0.450} \\
\hline & & $\mathrm{CT}$ & $1(5.6 \%)$ & $3(7.3 \%)$ & $0.71(0.07-7.3)$ & \\
\hline & & $\mathrm{TT}$ & $0(0 \%)$ & $2(4.9 \%)$ & $0.00(0.00-\mathrm{NA})$ & \\
\hline & Dominant & $\mathrm{CC}$ & $17(94.4 \%)$ & $36(87.8 \%)$ & 1.00 & \multirow[t]{2}{*}{0.410} \\
\hline & & CT-TT & $1(5.6 \%)$ & $5(12.2 \%)$ & $0.42(0.05-3.91)$ & \\
\hline & Recessive & CC-CT & $18(100 \%)$ & $39(95.1 \%)$ & 1.00 & \multirow[t]{2}{*}{0.220} \\
\hline & & $\mathrm{TT}$ & $0(0 \%)$ & $2(4.9 \%)$ & $0.00(0.00-\mathrm{NA})$ & \\
\hline & Overdominant & CC-TT & $17(94.4 \%)$ & $38(92.7 \%)$ & 1.00 & \multirow[t]{2}{*}{0.800} \\
\hline & & $\mathrm{CT}$ & $1(5.6 \%)$ & $3(7.3 \%)$ & $0.75(0.07-7.69)$ & \\
\hline & Log-additive & - & - & - & $0.43(0.07-2.78)$ & 0.300 \\
\hline \multirow[t]{10}{*}{ TLR9 $1635 \mathrm{G}>\mathrm{A}$} & Codominant & $\mathrm{AA}$ & $5(25 \%)$ & $15(34.1 \%)$ & 1.00 & \multirow[t]{3}{*}{0.760} \\
\hline & & GA & $11(55 \%)$ & $21(47.7 \%)$ & $1.57(0.45-5.47)$ & \\
\hline & & GG & $4(20 \%)$ & $8(18.2 \%)$ & $1.50(0.31-7.21)$ & \\
\hline & Dominant & AA & $5(25 \%)$ & $15(34.1 \%)$ & & \multirow[t]{2}{*}{0.460} \\
\hline & & GA-GG & $15(75 \%)$ & $29(65.9 \%)$ & $1.55(0.47-5.09)$ & \\
\hline & Recessive & AA-GA & $16(80 \%)$ & $36(81.8 \%)$ & 1.00 & \multirow[t]{2}{*}{0.860} \\
\hline & & GG & $4(20 \%)$ & $8(18.2 \%)$ & $1.12(0.3-4.28)$ & \\
\hline & Overdominant & AA-GG & $9(45 \%)$ & $23(52.3 \%)$ & 1.00 & \multirow[t]{2}{*}{0.590} \\
\hline & & GA & $11(55 \%)$ & $21(47.7 \%)$ & $1.34(0.46-3.87)$ & \\
\hline & Log-additive & - & - & - & $1.25(0.59-2.68)$ & 0.560 \\
\hline
\end{tabular}

$p \leq 0.050$ is considered significant

${ }^{\mathrm{a}} n$ number of examined fetuses and newborns

${ }^{\mathrm{b}} \mathrm{OR}$ odds ratio

${ }^{\mathrm{c}}$ CI confidence interval

${ }^{\mathrm{d}}$ Logistic regression model

uninfected controls. Taking into account all the analyzed alleles, the differences in their prevalence rates between the studied patient groups were not significant.

\section{Discussion}

The multiple SNP analysis, performed in our study for both the TLR4 and TLR9 SNPs, showed the GTG variants at the TLR4 $896 \mathrm{~A}>\mathrm{G}, 1196 \mathrm{C}>\mathrm{T}$, and TLR9 $1635 \mathrm{G}>\mathrm{A}$ polymorphisms to be significantly less frequent among the fetuses and newborns with congenital toxoplasmosis as compared to the uninfected offspring. Previously, no study had ever shown any simultaneous contribution of TLR4 and TLR9 SNPs to the occurrence of $T$. gondii infection. However, a combined involvement of other TLRs was reported in the development of T. gondii infection in mice as well as in humans $[25,26]$. Some participation of both TLR2 and TLR4 in triggering an immune response after $T$. gondii infection was observed in human macrophages, while a sort of cooperation among TLR7 TLR9, and TLR11 was shown in mice $[8,25,26]$. The outcomes of our study may suggest a contribution of all the analyzed polymorphic sites in the immune response against T. gondii. The studied TLR4 SNPs were in linkage disequilibrium; however, no difference was observed in the distribution of TLR 4 haplotypes between the T. gondii-infected fetuses and 
Table 3 Prevalence rates of the alleles at the TLR4 and TLR9 polymorphic sites

\begin{tabular}{|c|c|c|c|c|}
\hline \multicolumn{2}{|c|}{ Gene polymorphism } & \multicolumn{2}{|c|}{ No. ${ }^{\text {a }}$ of carriers with $T L R$ alleles (\%) } & \multirow[t]{2}{*}{$p$-Value } \\
\hline & & $\begin{array}{l}\text { Congenital } \\
\text { toxoplasmosis }\end{array}$ & $\begin{array}{l}\text { Uninfected } \\
\text { control }\end{array}$ & \\
\hline \multicolumn{5}{|c|}{$T L R 4896 \mathrm{~A}>\mathrm{G}$} \\
\hline Alleles & $\begin{array}{l}A \\
\text { G }\end{array}$ & $\begin{array}{l}37(97.4) \\
1(2.6)\end{array}$ & $\begin{array}{l}95(95.0) \\
5(5.0)\end{array}$ & 0.542 \\
\hline \multicolumn{5}{|c|}{ TLR4 $1196 \mathrm{C}>\mathrm{T}$} \\
\hline Alleles & $\begin{array}{l}\mathrm{C} \\
\mathrm{T}\end{array}$ & $\begin{array}{l}35(97.2) \\
1(2.8)\end{array}$ & $\begin{array}{l}75(91.5) \\
7(8.5)\end{array}$ & 0.252 \\
\hline \multicolumn{5}{|c|}{ TLR9 $1635 \mathrm{G}>\mathrm{A}$} \\
\hline Alleles & $\begin{array}{l}\mathrm{G} \\
\mathrm{A}\end{array}$ & $\begin{array}{l}19(47.5) \\
21(52.5)\end{array}$ & $\begin{array}{l}51(58.0) \\
37(42.0)\end{array}$ & 0.271 \\
\hline
\end{tabular}

$p \leq 0.050$ is considered significant

${ }^{\mathrm{a}} \mathrm{No}$. number

b Pearson's Chi-squared test

newborns and the uninfected controls. Besides the lack of papers on the role of genetic changes within TLR 4 in the development of toxoplasmosis, $T$. gondii infection was reported to trigger TLR4 to activate proinflammatory transcription factors and the expression of the pro-cytokines encoding genes $[6,8,10,27]$. Considering the polymorphic variability of TLR4, some studies showed a certain functional association of TLR4 SNPs with its activity [28-30]. The TLR4 $896 \mathrm{~A}>\mathrm{G}$ and $1196 \mathrm{C}>\mathrm{T}$ SNPs were described to result in cosegregating Asp299Gly and Thr399Ile missense mutations, respectively, that are localized in the ectocellular domain of the encoded protein [31,32]. The mutations were reported to diminish the TLR4 response to its ligand lipopolysaccharide (LPS) in humans, while the Asp299Gly modification was involved in the response interruption [31]. Additionally, the alteration caused a disruption of the TLR $\alpha$-helical protein structure and some extension of the $\beta$-strand [33]. The minor allele at the $896 \mathrm{~A}>\mathrm{G}$ SNP was reported to influence the dimerization of TLR4, although its expression was not altered [28]. Another study also showed both TLR4 $896 \mathrm{~A}>\mathrm{G}$ and $1196 \mathrm{C}>\mathrm{T}$ SNPs to impair the TLR4/MD dimerization required for activation of the downstream signaling [29]. In our study, the prevalence of minor alleles at both TLR4 SNPs was lower in congenitally infected fetuses and newborns, although the difference was not significant. The significantly lower frequency of GTG variants in the $T$. gondii-infected offspring might suggest a protective role of the mutations in the TLR4 gene against the development of parasitic infection. Some previous studies showed a dual function of TLR4 in the immune response after $T$. gondii infection [34-37]. In addition to triggering TLR4 signaling, associated with activation of the immune response, the parasite was also reported to use this molecule to escape the immune responses [38-40]. Hence, the modified TLR4 protein could be helpful for the host immune system to interrupt $T$. gondii dissemination in the infected organism. However, the number of fetuses and newborns congenitally infected with $T$. gondii and analyzed in the reported study was rather small; hence, the current results should be considered as preliminary and their further confirmation would require the analysis of a larger group of infected fetuses and newborns.

In the uninfected fetuses and newborns, the disruption of the TLR9 signaling pathway, engaged in the induction of type I IFNs, might also be driven by the altered TLR4 molecule. TLR4 was reported to be able to enter endosomes and to utilize TRAM and TRIF adapters to activate the IRF3 transcription factor that contributes to the production of type I IFNs $[10,41]$. In turn, TLR9 was observed to cooperate with IRF3 to induce inflammatory responses in liposome-DNAinjected mice [42]. Similarly to TLR4, the TLR9 molecule was suggested to be utilized by $T$. gondii in an immunosuppressive activity of the parasite that results in the inhibited mobilization of intracellular TNF- $\alpha$ to the surface of murine neutrophils [43]. Regarding TLR9 polymorphisms, it was reported that the $\mathrm{C}$ allele at the TLR $1635 \mathrm{G}>\mathrm{A}$ SNP correlated with toxoplasmic retinochoroiditis in Brazilian children with ocular toxoplasmosis [14]. Since the $1635 \mathrm{G}>\mathrm{A}$ SNP at the $T L R 9$ gene causes a synonymous amino acid change but no alterations in the regulatory site, it was suggested that other polymorphisms might affect the immune response against T. gondii as well [14].

Considering the outcomes of our study, the protective role of the analyzed TLR4 and TLR9 SNPs against congenital infection with $T$. gondii seems to be fairly plausible. The GTG multiple variants at the TLR4 and TLR9 SNPs were significantly less frequent among the fetuses and newborns with congenital toxoplasmosis than in the uninfected controls. The contribution of the presented multiple variants to the immune response against $T$. gondii seems to be possible. However, we suggest further studies with larger groups of patients to confirm the role of TLR SNPs in congenital toxoplasmosis, as well as to investigate the mechanisms which drive the participation of TLR polymorphisms in the immune response against the parasite.

Acknowledgments Sponsor: the Polish Ministry of Science \& Higher Education, Polish Mother's Memorial Hospital - Research InstituteYoung Researcher Internal Grant No. 2012/63-MN.

Compliance with ethical standards "All procedures performed in studies involving human participants were in accordance with the ethical standards of the institutional and/or national research committee and with the 1964 Helsinki declaration and its later amendments or comparable ethical standards."

Conflict of interest The authors declare that they have no conflict of interest. 
Open Access This article is distributed under the terms of the Creative Commons Attribution 4.0 International License (http:// creativecommons.org/licenses/by/4.0/), which permits unrestricted use, distribution, and reproduction in any medium, provided you give appropriate credit to the original author(s) and the source, provide a link to the Creative Commons license, and indicate if changes were made.

\section{References}

1. Nowakowska D, Stray-Pedersen B, Śpiewak E, Sobala W, Małafiej E, Wilczyński J (2006) Prevalence and estimated incidence of Toxoplasma infection among pregnant women in Poland: a decreasing trend in the younger population. Clin Microbiol Infect 12(9): 913-917

2. Nowakowska D, Colón I, Remington JS, Grigg M, Golab E, Wilczyński J, Sibley LD (2006) Genotyping of Toxoplasma gondii by multiplex PCR and peptide-based serological testing of samples from infants in Poland diagnosed with congenital toxoplasmosis. J Clin Microbiol 44(4):1382-1389

3. Nowakowska D, Wujcicka W, Sobala W, Śpiewak E, Gaj Z, Wilczyński J (2014) Age-associated prevalence of Toxoplasma gondii in 8281 pregnant women in Poland between 2004 and 2012. Epidemiol Infect 142(3):656-661

4. Remington JS, McLeod R, Wilson CB, Desmonts G (2011) Toxoplasmosis. In: Remington JS, Klein JO, Wilson CB, Nizet V, Maldonado YA (eds) Infectious diseases of the fetus and newborn infant, 7th edn. Elsevier Saunders, Philadelphia, pp 918-1041

5. Nowakowska D, Respondek-Liberska M, Gołąb E, Stray-Pedersen B, Szaflik K, Dzbenski TH, Wilczyński J (2005) Too late prenatal diagnosis of fetal toxoplasmosis: a case report. Fetal Diagn Ther 20(3):190-193

6. Wujcicka W, Wilczyński J, Nowakowska D (2013) SNPs in tolllike receptor (TLR) genes as new genetic alterations associated with congenital toxoplasmosis? Eur J Clin Microbiol Infect Dis 32(4): 503-511

7. Wujcicka W, Wilczyński J, Nowakowska D (2014) Do the placental barrier, parasite genotype and Toll-like receptor polymorphisms contribute to the course of primary infection with various Toxoplasma gondii genotypes in pregnant women? Eur J Clin Microbiol Infect Dis 33(5):703-709

8. Debierre-Grockiego F, Campos MA, Azzouz N, Schmidt J, Bieker U, Resende MG, Mansur DS, Weingart R, Schmidt RR, Golenbock DT, Gazzinelli RT, Schwarz RT (2007) Activation of TLR2 and TLR4 by glycosylphosphatidylinositols derived from Toxoplasma gondii. J Immunol 179(2):1129-1137

9. Debierre-Grockiego F, Niehus S, Coddeville B, Elass E, Poirier F, Weingart R, Schmidt RR, Mazurier J, Guérardel Y, Schwarz RT (2010) Binding of Toxoplasma gondii glycosylphosphatidylinositols to galectin-3 is required for their recognition by macrophages. J Biol Chem 285(43):32744-32750

10. Zare-Bidaki M, Hakimi H, Abdollahi SH, Zainodini N, Arababadi MK, Kennedy D (2014) TLR4 in Toxoplasmosis; friends or foe? Microb Pathog 69-70:28-32

11. Han SJ, Melichar HJ, Coombes JL, Chan SW, Koshy AA, Boothroyd JC, Barton GM, Robey EA (2014) Internalization and TLR-dependent type I interferon production by monocytes in response to Toxoplasma gondii. Immunol Cell Biol 92(10):872-881

12. Benson A, Pifer R, Behrendt CL, Hooper LV, Yarovinsky F (2009) Gut commensal bacteria direct a protective immune response against Toxoplasma gondii. Cell Host Microbe 6(2):187-196

13. Minns LA, Menard LC, Foureau DM, Darche S, Ronet C, Mielcarz DW, Buzoni-Gatel D, Kasper LH (2006) TLR9 is required for the gut-associated lymphoid tissue response following oral infection of Toxoplasma gondii. J Immunol 176(12):7589-7597

14. Peixoto-Rangel AL, Miller EN, Castellucci L, Jamieson SE, Peixe RG, Elias LdeS, Correa-Oliveira R, Bahia-Oliveira LM, Blackwell JM (2009) Candidate gene analysis of ocular toxoplasmosis in Brazil: evidence for a role for toll-like receptor 9 (TLR9). Mem Inst Oswaldo Cruz 104(8):1187-1190

15. Rey G, Skowronek F, Alciaturi J, Alonso J, Bertoni B, Sapiro R (2008) Toll receptor 4 Asp299Gly polymorphism and its association with preterm birth and premature rupture of membranes in a South American population. Mol Hum Reprod 14(9):555-559

16. Lorenz E, Hallman M, Marttila R, Haataja R, Schwartz DA (2002) Association between the Asp299Gly polymorphisms in the Tolllike receptor 4 and premature births in the Finnish population. Pediatr Res 52(3):373-376

17. Mockenhaupt FP, Hamann L, von Gaertner C, Bedu-Addo G, von Kleinsorgen C, Schumann RR, Bienzle U (2006) Common polymorphisms of toll-like receptors 4 and 9 are associated with the clinical manifestation of malaria during pregnancy. J Infect Dis 194(2):184-188

18. Roszak A, Lianeri M, Sowińska A, Jagodziński PP (2012) Involvement of Toll-like Receptor 9 polymorphism in cervical cancer development. Mol Biol Rep 39(8):8425-8430

19. Ricci E, Malacrida S, Zanchetta M, Mosconi I, Montagna M, Giaquinto C, De Rossi A (2010) Toll-like receptor 9 polymorphisms influence mother-to-child transmission of human immunodeficiency virus type 1. J Transl Med 8:49

20. Mesquita RT, Ziegler AP, Hiramoto RM, Vidal JE, PereiraChioccola VL (2010) Real-time quantitative PCR in cerebral toxoplasmosis diagnosis of Brazilian human immunodeficiency virusinfected patients. J Med Microbiol 59:641-647

21. Wujcicka W, Paradowska E, Studzińska M, Gaj Z, Wilczyński J, Leśnikowski Z, Nowakowska D (2015) TLR9 2848 GA heterozygotic status possibly predisposes fetuses and newborns to congenital infection with human cytomegalovirus. PLoS One 10(4):e0122831

22. Kirchner M, Sonnenschein A, Schoofs S, Schmidtke P, Umlauf VN, Mannhardt-Laakmann W (2013) Surface expression and genotypes of Toll-like receptors 2 and 4 in patients with juvenile idiopathic arthritis and systemic lupus erythematosus. Pediatr Rheumatol Online J 11(1):9

23. Meena NK, Verma R, Verma N, Ahuja V, Paul J (2013) TLR4 D299G polymorphism modulates cytokine expression in ulcerative colitis. J Clin Gastroenterol 47(9):773-780

24. Pandey S, Mittal B, Srivastava M, Singh S, Srivastava K, Lal P, Mittal RD (2011) Evaluation of Toll-like receptors 3 (c.1377C/T) and 9 (G2848A) gene polymorphisms in cervical cancer susceptibility. Mol Biol Rep 38(7):4715-4721

25. Andrade WA, Souza MdoC, Ramos-Martinez E, Nagpal K, Dutra MS, Melo MB, Bartholomeu DC, Ghosh S, Golenbock DT, Gazzinelli RT (2013) Combined action of nucleic acid-sensing Toll-like receptors and TLR11/TLR12 heterodimers imparts resistance to Toxoplasma gondii in mice. Cell Host Microbe 13(1):4253

26. Niehus S, Elass E, Coddeville B, Guérardel Y, Schwarz RT, Debierre-Grockiego F (2012) Glycosylphosphatidylinositols of Toxoplasma gondii induce matrix metalloproteinase-9 production and degradation of galectin-3. Immunobiology 217(1):61-64

27. McBerry C, Gonzalez RM, Shryock N, Dias A, Aliberti J (2012) SOCS2-induced proteasome-dependent TRAF6 degradation: a common anti-inflammatory pathway for control of innate immune responses. PLoS One 7(6):e38384

28. Figueroa L, Xiong Y, Song C, Piao W, Vogel SN, Medvedev AE (2012) The Asp299Gly polymorphism alters TLR4 signaling by interfering with recruitment of MyD88 and TRIF. J Immunol 188(9):4506-4515 
29. Yamakawa N, Ohto U, Akashi-Takamura S, Takahashi K, Saitoh S, Tanimura N, Suganami T, Ogawa Y, Shibata T, Shimizu T, Miyake K (2013) Human TLR4 polymorphism D299G/T399I alters TLR4/MD-2 conformation and response to a weak ligand monophosphoryl lipid A. Int Immunol 25(1):45-52

30. Yew KH, Carpenter C, Duncan RS, Harrison CJ (2012) Human cytomegalovirus induces TLR4 signaling components in monocytes altering TIRAP, TRAM and downstream interferon-beta and TNF-alpha expression. PLoS One 7(9):e44500

31. Arbour NC, Lorenz E, Schutte BC, Zabner J, Kline JN, Jones M, Frees K, Watt JL, Schwartz DA (2000) TLR4 mutations are associated with endotoxin hyporesponsiveness in humans. Nat Genet 25(2):187-191

32. Bell JK, Mullen GE, Leifer CA, Mazzoni A, Davies DR, Segal DM (2003) Leucine-rich repeats and pathogen recognition in Toll-like receptors. Trends Immunol 24(10):528-533

33. Gibrat JF, Garnier J, Robson B (1987) Further developments of protein secondary structure prediction using information theory. New parameters and consideration of residue pairs. J Mol Biol 198(3):425-443

34. Barbosa BF, Lopes-Maria JB, Gomes AO, Angeloni MB, Castro AS, Franco PS, Fermino ML, Roque-Barreira MC, Ietta F, MartinsFilho OA, Silva DA, Mineo JR, Ferro EA (2015) IL10, TGF beta1, and IFN gamma modulate intracellular signaling pathways and cytokine production to control Toxoplasma gondii infection in BeWo trophoblast cells. Biol Reprod 92(3):82. doi:10.1095/biolreprod. 114.124115

35. Hunter CA, Sibley LD (2012) Modulation of innate immunity by Toxoplasma gondii virulence effectors. Nat Rev Microbiol 10(11): 766-778
36. Morgado P, Sudarshana DM, Gov L, Harker KS, Lam T, Casali P, Boyle JP, Lodoen MB (2014) Type II Toxoplasma gondii induction of CD40 on infected macrophages enhances interleukin-12 responses. Infect Immun 82(10):4047-4055

37. Rosowski EE, Nguyen QP, Camejo A, Spooner E, Saeij JP (2014) Toxoplasma gondii Inhibits gamma interferon (IFN-gamma)- and IFNbeta-induced host cell STAT1 transcriptional activity by increasing the association of STAT1 with DNA. Infect Immun 82(2):706-719

38. Lee EJ, Heo YM, Choi JH, Song HO, Ryu JS, Ahn MH (2008) Suppressed production of pro-inflammatory cytokines by LPSactivated macrophages after treatment with Toxoplasma gondii lysate. Korean J Parasitol 46(3):145-151

39. Leng J, Denkers EY (2009) Toxoplasma gondii inhibits covalent modification of histone $\mathrm{H} 3$ at the IL-10 promoter in infected macrophages. PLoS One 4(10):e7589

40. Mun HS, Aosai F, Norose K, Piao LX, Fang H, Akira S, Yano A (2005) Toll-like receptor 4 mediates tolerance in macrophages stimulated with Toxoplasma gondii-derived heat shock protein 70 . Infect Immun 73(8):4634-4642

41. Kawai T, Akira S (2011) Toll-like receptors and their crosstalk with other innate receptors in infection and immunity. Immunity 34(5): $637-650$

42. Walker WE, Booth CJ, Goldstein DR (2010) TLR9 and IRF3 cooperate to induce a systemic inflammatory response in mice injected with liposome:DNA. Mol Ther 18(4):775-784

43. Bennouna S, Sukhumavasi W, Denkers EY (2006) Toxoplasma gondii inhibits toll-like receptor 4 ligand-induced mobilization of intracellular tumor necrosis factor alpha to the surface of mouse peritoneal neutrophils. Infect Immun 74(7):4274-4281 